\title{
Mechanisms of alcoholic liver injury
}

\author{
Samuel W French MD FRCPSC
}

SW French. Mechanisms of alcoholic liver injury. Can J Gastroenterol 2000;14(4):327-332. There have been numerous recent advances in the understanding of the mechanisms of alcoholic liver disease pathogenesis. Endotoxin-induced Kupffer cell activation plays a role in cytokine-mediated inflammatory changes in the liver, and this can be blocked by a diet high in saturated fat, by a diet containing lactobacillus, which does not produce endotoxin, by neomycin antibiotic sterilization of the gut, by eliminating Kupffer cells, or by removing tumour necrosis factor-alpha with antibody or by using tumour necrosis factor-alpha knockout mice. The fatty liver component is mainly the result of the nicotinamide adenine dinucleotide/reduced nicotinamide adenine dinucleotide redox shift to the reduced state by ethanol oxidation generation of reduced nicotinamide adenine dinucleotide, although this too can be blocked by a diet high in saturated fat. Hepatocytic enlargement occurs due to ethanol-induced inhibition of the ubiquitin-proteasome pathway of cytoplasmic protein degradation and the retention of oxidized proteins in hepatocytes. The liver is scarred by stellate cells that have been activated by inflammatory cytokines and growth factors produced by activated Kupffer cells, and by bile ductule metaplasia. Mallory bodies and balloon cell degeneration develop through the ethanol-induced oxidative stress-protein kinase activation pathway, inhibition of phosphatase activity and inhibition of the ubiquitin-proteasome pathway.

Key Words: Cytokines; Ethanol; Growth factors; Kupffer cells, Stellate cells

\section{Mécanismes d'apparition des lésions hépatiques dues à l'alcool}

RÉSUMÉ : De nombreux progrès ont été réalisés récemment dans la compréhension des mécanismes de la pathogenèse du foie alcoolique. L'activation des cellules de Kupffer, d'origine endotoxinique, joue un rôle dans les changements inflammatoires médiés par les cytokines, qui se produisent dans le foie. Le processus peut être inhibé par un régime riche en graisses saturées ou contenant des Lactobacillus, qui ne produisent pas d'endotoxine, la stérilisation de l'intestin à la néomycine, l'élimination des cellules de Kupffer, ou encore par l'élimination du facteur-alpha de nécrose des tumeurs à l'aide d'anticorps ou l'utilisation du facteur-alpha de nécrose des tumeurs inactivé de souris. La stéatose hépatique résulte surtout du passage de l'oxydoréduction du nocotinamide adénine dinucléotide/nocotinamide adénine dinucléotide réduit à l'état réduit par la production de nocotinamide adénine dinucléotide réduit par l'oxydation de l'éthanol, bien que le processus puisse, lui aussi, être bloqué par un régime riche en graisses saturées. L'augmentation de volume des hépatocytes est attribuable à l'inhibition de la chaîne ubiquitine-protéasome de la dégradation des protéines cytoplasmiques et à la rétention des protéines oxydées dans les hépatocytes. L'intégrité du foie est attaquée par les cellules étoilées activées par les cytokines inflammatoires et les facteurs de croissance produits par l'activation des cellules de Kupffer, ainsi que par la métaplasie des voies biliaires. L'activation de la protéine-kinase associée au stress oxydatif de l'éthanol, l'inhibition de l'activité de la phosphatase et l'inhibition de la chaîne ubiquitine-protéasome sont responsables de la dégénérescence des cellules ballonisées et de la production des corps de Mallory.
$\mathrm{P}$ rogress in understanding how ethanol causes liver damage has been made possible through the use of rodent models of alcoholic liver disease (ALD). Isolation of liver cellular constituents in culture and the use of mouse knockout models have further focused investigations of the mechanisms involved. The roles of inflammatory cytokines and chemokines, as well as of growth factors have been further defined (Figure 1). Progress in understanding the role of metabolic changes and consequences of oxidant stress has revealed new concepts regarding liver injury and subsequent fibrosis and cirrhosis in animal models. The mechanisms of hepatocellular swelling, cytokeratin aggregation (ie, Mallory bodies [MBs]) and apoptosis are better understood. This progress is the subject of the present review.

This mini-review was prepared from a symposium on the mechanisms of liver injury, presented at the World Congress of Gastroenterology in Vienna, Austria, September 10, 1998

Harbor-UCLA Medical Center, Torrance, California, USA

Correspondence and reprints: Dr Samuel W French, Department of Pathology, 1000 West Carson Street, Torrance, California 90509 , USA.

Telephone 310-222-2643, fax 310-222-5333, e-mail FRENCH@AFP76.HUMC.EDU

Received for publication December 14, 1998. Accepted December 17, 1998 


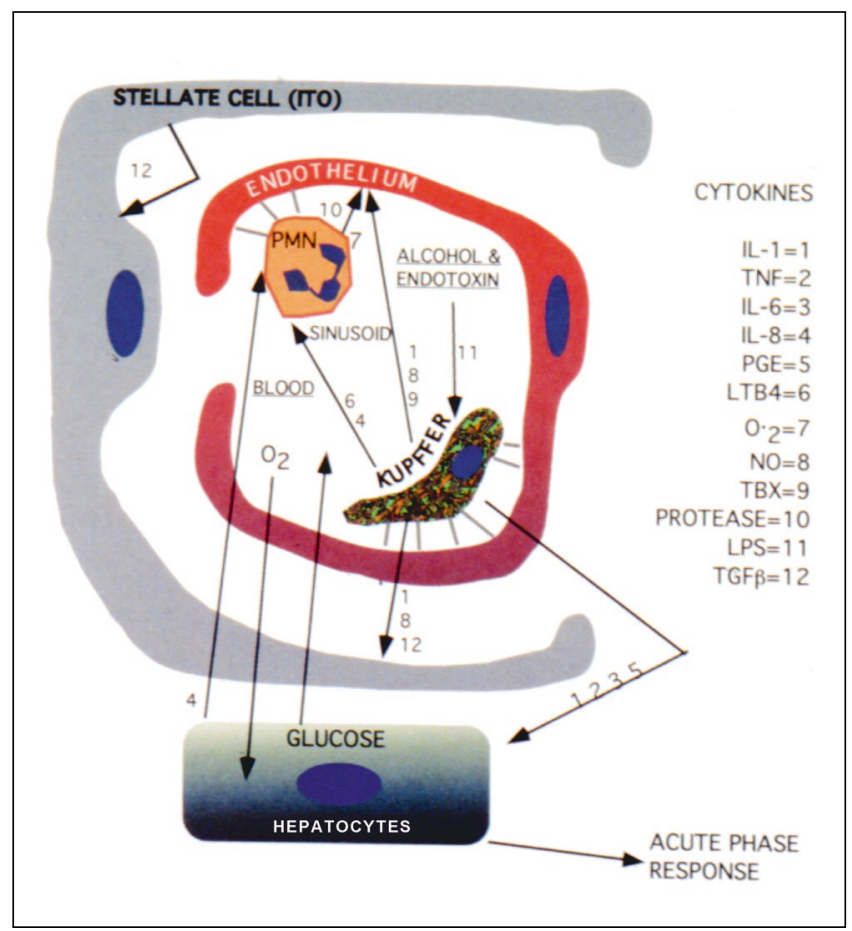

Figure 1) Schematic representation of the four types of cells involved in the focal sinusoidal inflammatory response to Kupffer cell activation in alcoholic liver disease. Cell to cell communications result from various secretory products and cell receptors. Cytokines, proteases, free radicals, eicosanoids and endotoxin are involved in paracrine and autocrine stimulated responses (arrows). IL Interleukin; LPS Lipopolysaccharide; LTB4 Leukotriene B4; NO Nitric oxide; PGE Prostaglandin E; PMN Polymorphonuclear leukocytes; TBX T-box; TGF $\beta$ Transforming growth factor-beta; TNF Tumour necrosis factor

The role of the Kupffer cell as the primary target of ethanol liver damage has been summarized in depth by Lands (1), and was first revealed with the observation by Nanji et al (2) that endotoxin levels were elevated in the blood of rats fed ethanol intragastrically for one to two months. They noted a significant correlation between endotoxin (lipopolysaccharide [LPS]) levels and the severity of the liver pathology (ALD) that induced fatty change and liver cell necrosis. Nanji et al (3) showed subsequently, using the same model, that replacing gut bacteria with lactobacillus, which do not produce endotoxemia, prevented the development of ALD pathology. This has been confirmed by reducing LPS in the blood by feeding the rats neomycin to sterilize the gut (4). The significance of this observation became apparent when it was shown, with the use of the same rat model, that the liver pathology caused by ethanol feeding was largely prevented by eliminating the Kupffer cells with gadolinium chloride treatment (5). Because Kupffer cells are activated by LPS to produce a large number of inflammatory cytokines and bioactive, potentially hepatotoxic substances, it was reasonable to suspect this cell as the central mediator of ALD.

One of the candidate cytokines produced by Kupffer cells in response to LPS is tumour necrosis factor-alpha (TNF $\alpha$ ). This cytokine is elevated in the blood of patients with ALD, as is LPS $(6,7)$, and probably accounts for the anorexia that these patients experience. Nanji et al (8) reported that livers from rats with experimental ALD showed increased TNF $\alpha$ mRNA expression. Kupffer cells isolated from the rat model showed increased gene expression of TNF $\alpha$, interleukin (IL) -6 and transforming growth factor-beta (TGF $\beta$ ) (9). In fact, antibodies to TNF $\alpha$ attenuated the ALD pathology $(10,11)$, further substantiating that Kupffer cell overproduction of TNFo is an important step in the development of ALD.

Of course, Kupffer cell activation by LPS and ethanol leads to increased secretion of cytokines IL-1, -6 and -8 , TGF $\beta$ and the chemokines chemokine cytokine-induced neutrophil chemoattractant, macrophage inflammatory protein (MIP), monocyte chemoattractant protein-1 (MCP-1), platelet-activating factor and insulin-like growth factor 1 (IGF-1), through the activation of nuclear factor kappa $B$ (NFkB) transcription (1). Oxidative stress activates NFkB, leading to the induction of inducible nitric oxide synthase and nitric oxide generation (1). Through the CD14, receptor LPS activates phospholipase $\mathrm{C}$ and protein kinase $\mathrm{C}$ (PKC) in the Kupffer cell (12), increases cytosolic calcium and increases reduced nicotinamide adenine dinucleotide phosphate oxidase generation of superoxide (1). The LPSCD14 response is augmented by the liver cell release of LPS-binding protein, an acute phase response protein stimulated by IL-6 produced by the Kupffer cell. Cyclo-oxygenase-2 is induced in the Kupffer cells, which leads to an increase in thromboxane $\mathrm{A}_{2}$, a potent agonist for vasoconstriction, thrombosis, ischemic necrosis and inflammation in the liver (13). This is augmented by activation of phospholipase $\mathrm{A}_{2}$ generation of arachidonic acid (13). PKC is also activated by oxidative stress, which activates tyrosine kinase and the mitogen-activated protein (MAP) kinase cascade. Both the increase in cytosolic calcium and the MAP kinase cascade increase phospholipase $A_{2}$, which probably accounts for the activation and sensitization of the Kupffer cell to augment further injury caused by further challenges with ethanol. Kupffer cells undergo an acute desensitization after challenge followed by increased sensitivity to rechallenge a few hours later (14).

Kupffer cell-mediated injury is amplified by cytokinemediated induction of cell adhesion molecules (integrins, ie, intercellular adhesion molecule, vascular cell adhesion molecule, IL-8 and leukotriene $\mathrm{B}_{4}$.) Monocytes, lymphocytes and neutrophils are thus immobilized within the sinusoid. These inflammatory foci generate superoxide and proteases. Myeloperoxidase generates hypochloric acid, leading to focal damage and hepatocellular necrosis.

Active Kupffer cells also release proteases such as urokinase, which may affect neighbouring hepatocytes because urokinase activates hepatocyte growth factor (HGF) to stimulate hepatocellular regeneration.

There are three mitigating circumstances where ethanol ingestion may not activate Kupffer cells. For instance, a high fat diet is required if ethanol is to induce ALD pathology by activating Kupffer cells (15), ie, NFאB activation, TNF $\alpha$ and MIP-1 mRNA expression. Another modifier is the in- 
hibitory action of acetaldehyde. Drugs that block acetaldehyde dehydrogenase and increase the levels of liver tissue acetaldehyde prevent the ALD pathology and Kupffer cell $\mathrm{NF} \kappa \mathrm{B}$ activation (16). A third factor is that increased nonheme iron levels in Kupffer cells are critical to ethanol activation of Kupffer cells and TNF $\alpha$ expression (15). The latter may be the mechanism of cirrhosis formation that is observed in the rat ALD model when a small amount of carbonyl iron is added to the diet (17).

Of great interest is the mechanism of liver cell necrosis in ALD. In the rat model as well as in human ALD, apoptosis is clearly increased $(18,19)$. The apoptotic process is short lived ( 3 to $5 \mathrm{~h}$ ), so the phenomenon is easy to miss. Because TNFo can induce apoptosis in vitro (20), this may be the mechanism in ALD; however, NFKB activation prevents TNFa-induced apoptosis. One theory is that glutathione depletion in the mitochondria, which results from oxidative stress in hepatocytes, leads to membrane permeability transition change, calcium influx into the mitochondria, mitochondrial swelling and release of cytochrome C. Cytochrome C binds to Apaf-1 to activate caspase 9, which activates caspase 3 , triggering a cascade of events that lead to programmed cell death and the breakup of the hepatocytes into small fragments followed by their removal by phagocytosis (20). Others postulate that TNF $\alpha$ signalling involves sphingomyelinase formation of ceramide as a second messenger that triggers the formation of reactive oxygen species, which initiates mitochondrial membrane permeability transition change, which results from the alteration of complex III of respiration (21).

Hepatocellular changes that are probably independent of Kupffer cell activation include fat accumulation, fatty acid metabolic changes, loss of glycogen stores, inhibition of proteolysis, hyperphosphorylation of cytokeratins and the oxidation of lipids, proteins and DNA.

The accumulation of fat in the form of triglyceride is multifactorial in terms of the mechanisms involved. Most likely, fat accumulates mainly due to the decreased beta oxidation of fatty acids by the mitochondria due to the shift in the oxidized form of nicotinamide adenine dinucleotide to reduced nicotinamide adenine dinucleotide ratio (22). Fatty acid metabolism is greatly altered due to the induction of cytochrome P450 (CYP) enzymes, which peroxidate, hydroxylate and epoxidate them to bioactive intermediates (hydroxyeicosatetraenoic acids and epoxyeicosatrienoic acids) (23), and enzymes that metabolize arachidonic acid to bioactive prostaglandins and thromboxanes (13). Lipid peroxidation leads to protein adduct formation, which correlates positively with the severity of liver pathology in the rat and humans $(24,25)$. Intermediates are formed from fatty acid hydroxylation as the result of the induction of cytochromes such as CYP 4A1, CYP 3A1, CYP 2B1 and CYP 1B1 (26-28). The adducts formed with proteins act as neoantigens on the liver cell surface, and antibodies bind to these adducts on the plasma membrane to damage the liver cells, hypothetically, by antibody-assisted lymphotoxicity mechanisms.
Liver cell proteins become damaged through peroxidation by the CYP 2E1-generated free radical formation of peroxyls and alkoyls, which leads to the accumulation of oxidized proteins in hepatocytes (29). Concomitantly, ethanol feeding leads to a decrease in ubiquitin in hepatocytes (30). Ubiquitin is necessary to prepare the cytosolic proteins for degradation by the proteasome pathway. Compounding this problem in the removal of cytosolic proteins, ethanol feeding leads to inhibition of the proteolytic enzymes in the proteasome (31). Consequently, proteins accumulate in hepatocytes (31), which probably accounts for the 'ballooning' of hepatocytes seen in ALD. Oxidized proteins, in increased amounts, inhibit protein degradation by the proteasomes (32).

Oxidation of mitochondrial DNA is also induced by chronic alcohol ingestion (33). Mitochondrial DNA deletions occur in the liver of alcoholics associated with steatosis (34). Both errors in cytosine loci where wrong nucleotides are incorporated during replication of DNA cause point mutations (34). In addition DNA, deletions are observed in the liver mitochondria of alcoholics (35). These changes are reversible when alcoholic patients stop drinking (36).

The cell origin of collagen in the liver, including the source of scarring and cirrhosis, is the stellate cell, formerly known as the Ito cell or lipocyte. Recent focus on the role of this cell in ALD has revealed that it is activated by fibronectin and cytokines IL-1, TGF $\beta$ and IL-6. Fibronectin is derived from sinusoidal endothelial cells $(37,38)$. It is increased in the space of Disse early in the course of ethanol feeding (39), followed by an increase in collagen IV (40), followed by capillarization of the sinusoid by laying down basement membrane by the endothelial cells (40). Although the focal activation of stellate cells that is due to focal necrosis occurs early in the course of experimental ALD (one to two months of alcohol feeding), diffuse activation of stellate cells occurs late in the course of ethanol feeding (five to six months of feeding ethanol) (41). Extensive centrilobular perisinusoidal fibrosis due to diffuse stellate cell activation requires polyunsaturated fatty acids in the diet $(42-44)$ and a high fat diet (14).

Activation of stellate cells, either focally or diffusely, probably results from paracrine stimulation by Kupffer cells, endothelium and hepatocytes, which release TGF $\beta$ IL-1, TGF $\alpha$, platelet-derived growth factor (PDGF), TNF $\alpha$ and IGF-1 $(37,45,46)$. Acetaldehyde (15) and interferon (45) inhibit stellate cell activation. This may explain why activation of stellate cells in vivo takes so long to be induced by ethanol. Activated stellate cells become responsive or hyperresponsive in tissue culture to cytokines and growth factors through paracrine and autocrine mechanisms. These factors include IGF-1, TGF $\alpha$, TGF $\beta$, colony stimulating factor-1, HGF, IL-6, PDGF, epidermal growth factor (EGF), MCP-1, fibronectin and endothelin-1 $(37,46)$. The activated stellate expresses a complex phenotype that includes the following newly acquired functions: proliferation, migration, contraction, collagen and fibronectin synthesis, white blood cell chemotaxis and collagenase secretion. Focal in- 


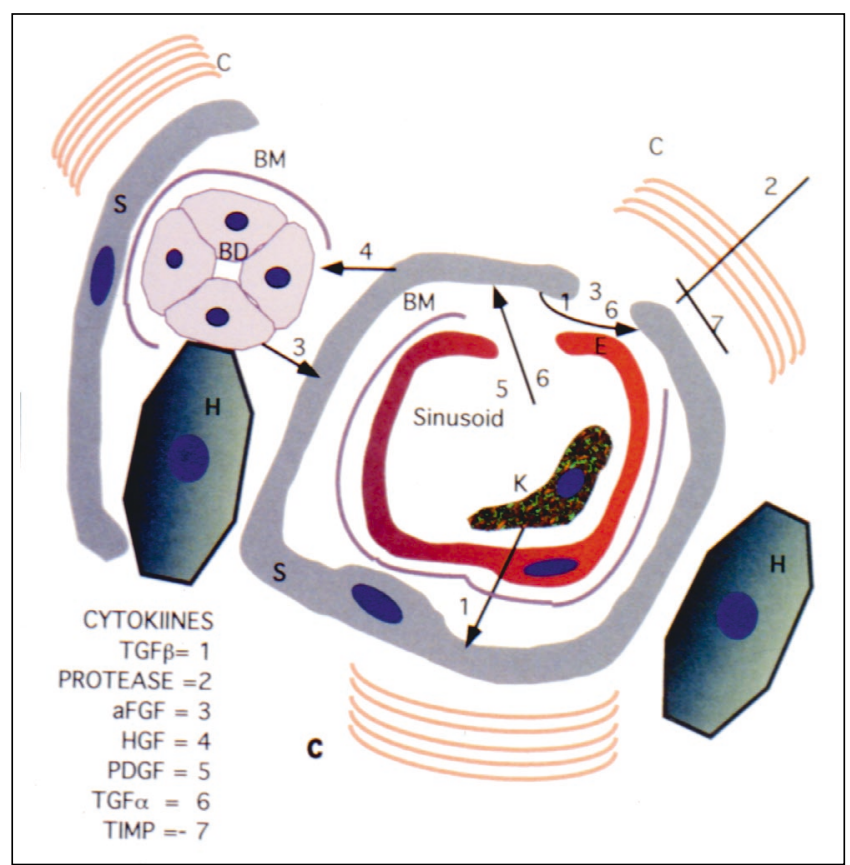

Figure 2) Schematic representation of pericellular fibrosis and bile duct metaplasia induced fibrosis. Cytokines, proteases, growth factors and inhibitors are involved. aFGF Acidic fibroblast growth factor; BD Bile duct; BM Basement membrane; C Collagen; E Endothelium; H Hepatocyte; HGF Hepatocyte growth factor; K Kupffer cell; PDGF Platelet-derived growth factor; S Stellate Cell; TGF Transforming growth factor; TIMP Tissue inhibitors of matrix metalloproteinases

jury, leading to local scarring, is quickly resolved unless the stimulus is sustained. It is not known which factors perpetuate the scarring process that leads to cirrhosis. Scars that do not lead to septal formation can be completely removed by collagenase over time. Thus, permanent scarring is the result of the balance between collagen synthesis and degradation over time. Collagenase inhibitors (tissue inhibitors of matrix metalloproteinases) may be important in maintaining this balance (47).

Activation of stellate cells leads to the deposit of a great variety of extracellular matrix proteins (37) secreted by the stellate cells. Among these is hyaluronic acid (37), which is elevated in the blood during active liver fibrosis. Hyaluronic acid is normally cleared by hepatic endothelial cells, but in hepatic fibrosis in ALD the endothelial cells fail to clear it (48). The CD44 receptor isoform for hyaluronic acid is expressed by stellate cells in liver injury, and this may be a factor in the migration of stellate cells to the site of injury in the localized fibrosis in ALD (49).

One important property of the activated stellate cell is its enhanced contraction in response to endothelin-1 from endothelial cells (50). Thus, activated stellate cell contraction may explain the damage to hepatocytes that occurs in the centrilobular zone because of the liver hypoxia that develops in rats fed ethanol chronically (51).

One important mechanism by which stellate cell proliferation plays a role in the pathogenesis of alcoholic cirrhosis involves the liver cell bile ductular metaplasia phenomenon (52). In this phenomenon, liver cells undergo a phenotypic switch to form ductules in the limiting plate of hepatocytes at the periportal zone during the development of cirrhosis (18). The stellate cells located next to the switched hepatocytes proliferate to provide stroma for the newly formed ductules in a process that recapitulates bile duct formation in the fetal liver (53). This is a self-perpetuating interaction that leads to progressive fibrosis and cirrhosis due to growth factors released by the ductules (acidic fibroblast growth factor), which stimulates stellate proliferation, and HGF and stem cell factor released by the stellate cells, which stimulates bile ductule proliferation $(54,55)$. Endothelin-1 (56), TGF $\beta$ (57), EGF and IL-6 (58) may also participate in this stimulation-proliferation process of periportal fibrosis (Figure 2).

The role of MB formation in ALD has recently been better defined. The formation of MBs in drug-primed mice fed ethanol intragastrically for seven days provides a model to determine their pathogenesis (59) because of the short interval between starting ethanol ingestion and $\mathrm{MB}$ formation. In this model, CYP 2E1 was induced and cytokeratin 8 was increased, whereas the mRNA for CYP 2E1 tended to decrease and cytokeratin- 8 mRNA was significantly decreased. The discrepancy between the protein levels and the mRNA expression indicates an inhibition of proteolysis by the proteasome as the mechanism for cytokeratin-8 and CYP 2E1 accumulation. This fits the hypothesis that MBs result from the accumulation of cytokeratins that are conformationally altered so as to resist proteolysis, which is inhibited by ethanol ingestion (60). Evidence that the MBs are composed of cytokeratins that have undergone profound alterations in their conformation was obtained by infrared spectroscopy of the amide I spectrum of isolated mouse and human MBs (61).

Hyperphosphorylation of MBs (60) likely accounts for their conformational change. Secondary ubiquitination (62) of MBs may add to their resistance to proteolysis. The question of what is the mechanism of hyperphosphorylated of MBs remains. Studies on MB phosphorylation indicate that $\mathrm{PKC}$ is the main kinase involved, probably triggered by oxidative stress. Ethanol induces hyperphosphorylation of cytokeratins in hepatocytes within 15 mins in primary tissue culture of hepatocytes through a PKC mechanism (63). Okadaic acid increases phosphorylation of liver cytokeratins in vivo within 15 mins by inhibiting serine-threonine phosphases 1 and 2A (60). Hyperphosphorylation was indicated using an antibody to phosphothreonine. Aggregates of cytokeratin resulted, and these stained positive for cytokeratins, ubiquitin and phosphothreonine in the same manner as do MBs (60). The aggregates were present in 'empty' hepatocytes that failed to stain for cytokeratins except where the aggregates were found. The 'empty' cells correspond to the balloon cells containing MBs seen in ALD in humans (64). These acute changes induced by okadaic acid occurred at the same time that NFKB was activated (60), which is a further indication that oxidative stress was involved (65). The hyperphosphorylation of serine residues (66) as well as the involvement of PKC has been corroborated, although other kinases may also be involved (67). 


\section{REFERENCES}

1. Lands WFM. Cellular signals in alcohol-induced liver injury: A review. Alcohol Clin Exp Res 1995;19:928-38.

2. Nanji AA, Khettry U, Sadrzadeh SMH, Yamanaka T. Severity of liver injury in experimental alcoholic liver disease: Correlation with plasma endotoxin, prostaglandin $\mathrm{E}_{2}$, leukotriene $\mathrm{B}_{4}$ and thromboxane $\mathrm{B}_{2}$. Am J Pathol 1993;142:367-73.

3. Nanji A, Khettry U, Sadrzadeh S. Lactobacillus feeding reduces endotoxemia and severity of experimental alcoholic liver disease. Proc Soc Exp Biol 1994;205:243-7.

4. Adachi Y, Moore L, Bradford B, Thurman R. Antibiotics prevent liver injury in rats following long-term exposure to ethanol.

Gastroenterology 1995;108:218-24.

5. Adachi Y, Bradford B, Gao W, Thurman R. Inactivation of Kupffer cells prevents early alcohol-induced liver injury. Hepatology 1994;20:453-60.

6. McClain CJ, Hill DB, Schmidt J. Cytokines and alcoholic liver disease. Semin Liver Dis 1993;13:170-82.

7. Hill D, Shedofsky S, McClain CJ. Cytokines and liver disease. In: Remick D, Friedland J, eds. A Cytokines in Health and Disease, 2nd edn. New York: Marcel Dekker, Inc, 1997:401-25.

8. Nanji AA, Zhao S, Sadrzadeh SM. Use of reverse transcriptionpolymerase chain reaction to evaluate in vivo cytokine gene expression in rats fed ethanol for long periods. Hepatology 1994;19:1483-7.

9. Kaminura S, Tsukamoto H. Cytokine gene expression by Kupffer cells in experimental alcoholic liver disease. Hepatology 1995;21:1304-9.

10. Imuro Y, Gallucci R, Luster ML, Kano H, Thurman RG. Antibodies to tumor necrosis factor alpha attenuate hepatic necrosis and inflammation caused by chronic exposure to ethanol in the rat. Hepatology 1997;26:1530-7.

11. Yin M, Kono H, Bradford BU, Thurman RO. Development of a new enteral mouse model using knock out technology to study alcohol-induced liver injury: involvement of TNF $\alpha$. Hepatology 1998;28:321. (Abst)

12. Hoek JB, Kholodenko BN. The intracellular signaling network as a target for ethanol. Alcohol Clin Exp Res 1998;22:224S-30S.

13. Nanji AA, Miao L, Thomas P, et al. Enhanced cyclooxygenase-2 gene expression in alcoholic liver disease in the rat. Gastroenterology 1997;112:943-51.

14. Enomoto N, Ikejima K, Bradford B, et al. Alcohol causes both tolerance and sensitization of rat Kupffer cells via mechanisms dependent on endotoxin. Gastroenterology 1998;115:443-51.

15. Tsukamoto H, Lin M, Ohata M, Giulivi C, French SW, Brittenham $G$. Iron primes for hepatic macrophages NFKB activation in alcoholic liver injury. Am J Physiol 1999;277:G1240-50.

16. Jokelainen $\mathrm{K}$, Lindros $\mathrm{KO}$, Nanji AA. Increased acetaldehyde in vivo inhibits $\mathrm{NF}_{\kappa} \mathrm{B}$ activation through $1 \mathrm{~KB} \alpha$ preservation and ameliorates liver injury in experimental alcoholic liver disease. Hepatology 1998;28:499. (Abst)

17. Tsukamoto H, Horne W, Kamimura S, et al. Experimental liver cirrhosis induced by alcohol and iron. J Clin Invest 1995;96:620-30.

18. Yacoub LK, Fogt F, Geriniuviene B, Nanji AA. Apoptosis and Bcl-2 protein expression in experimental alcoholic liver disease in the rat. Alcohol Clin Exp Res 1995;19:854-9.

19. French SW, Nash J, Shitabata P, et al. Pathology of alcoholic liver disease. Semin Liver Dis 1993;13:154-69.

20. Reed JC. Cytochrome C: Can't live with it - can't live without it. Cell 1997;91:559-62.

21. Colell A, Garcia-Ruiz C, Kaplowitz N, Fernandez-Chica JC. Hepatic mitochondrial glutathione depletion and cytokine-mediated alcoholic liver disease. Alcohol Clin Exp Res 1998;22:27-8.

22. Fromenty B, Pessayre D. Inhibition of mitochondrial beta-oxidation as a mechanism of hepatotoxicity. Pharmacol Ther 1995;67:101-54.

23. French SW, Morimoto M, Reitz R, et al. Lipid peroxidation, CYP2E1 and fatty acid metabolism in alcoholic liver disease. J Nutr 1997;127:9075-115.

24. Albano E, Clot P, Morimoto M, Tamasi A, Ingelman-Sundberg M, French SW. Role of cytochrome P450 2E1-dependent formation of hydroxyethyl free radicals in the development of liver damage in rats intragastrically fed with ethanol. Hepatology 1996;23:155-63.

25. Albano E, French SW, Ingelman-Sundberg M. Cytochrome P450 2E1, hydroxyethyl free radicals and immune reactions associated to alcoholic liver disease. Alcohol Clin Exp Res 1998;22:739-42.

26. Amet Y, Lucas D, Zhang-Gouillon ZQ, French SW. P450-dependent metabolism of lauric acid in alcoholic liver disease: comparison between rat liver and kidney microsomes. Alcohol Clin Exp Res 1998;22:455-62.

27. Amet Y, Berthou F, French SW. Alcohol-inducible P450 in rat liver and kidney microsomes. Fatty acid metabolism. Alcohol Clin Exp Res 1998;22:744-6.

28. Lytton SD, Helander A, Zhang-Gouillon ZQ, et al. Autoantibodies against cytochromes P-4502E1 and P-4503A in alcoholics. Mol Pharmacol 1999;55:223-33.

29. Dean RT, Fu S, Stocker R, Davies MJ. Biochemistry and pathology of radical-mediated protein oxidation. Biochem J 1997;324:1-18.

30. Zhang-Gouillon ZQ, Yuan QX, French BA, et al. Effects of DB-cAMP on ubiquitin and CYP2E1 levels in experimental ethanol-induced liver disease. Hepatology 1996;24:442. (Abst)

31. Donohue TM Jr, Zetterman RK, Zhang-Gouillon ZQ, French SW. Peptidase activities of the multicatalytic protease in rat liver after voluntary and intragastric ethanol administration. Hepatology 1998;28:486-91.

32. Grune T, Reinheckel T, Davies KJA. Degradation of oxidized proteins in mammalian cells. FASEB J 1997;11:526-34.

33. Wieland P, Lauterburg BH. Oxidation of mitochondrial proteins and DNA following administration of ethanol. Biochem Biophys Res Commun 1995;213:815-9.

34. Fromenty B, Grimbe TS, Mansowie A, et al Hepatic mitochondrial DNA deletion in alcoholics: association microvesicular steatosis. Gastroenterology 1995;108:193-200.

35. Mansowi A, Fromenty B, Berson A, et al. Multiple hepatic DNA deletions suggest premature oxidative aging in alcoholics. J Hepatol 1997;27:96-102.

36. Tsutsumi M, Tsuchishima M, Shiroeda K, Deshima Y, Kawahara H, Takase S. Reversibility of mitochondrial DNA mutation in alcoholic liver disease. Hepatology 1998;28:669. (Abst)

37. Friedman SL. Molecular mechanisms of hepatic fibrosis and principles of therapy. J Gastroenterology 1997;32:424-30.

38. Janagen WR, Rockey DC, Koteliansk VE, Wang SS, Bissell DM. Expression of variant fibronectins in wound healing. Cellular source and biological activity of the EIIIA segment in rat hepatic fibrogenesis. J Cell Biol 1994;127:2037-48.

39. Gillis SE, Nagy LE. Deposition of cellular fibronectin increases before stellate activation in rat liver during ethanol feeding. Alcohol Clin Exp 1997;21:857-61.

40. Urashima S, Tsutsumi M, Nakase K, Wang J-S, Takada A. Studies on capillarization of the hepatic sinusoids in alcoholic liver disease. Alcohol Alcohol 1993;28:77-84.

41. Takahashi H, Wang K, Jui L, Nanji AA, Mendenhall CS, French SW Effect of dietary fat on Ito cell activation by chronic ethanol intake: A long-term serial morphometric study on alcohol-fed and control rats. Alcohol Clin Exp Res 1991;15:1060-6.

42. Nanji AA, Mendenhall CL, French SW. Beef fat prevents alcoholic liver disease in the rat. Alcohol Clin Exp Res 1989;13:15-9.

43. Morimoto M, Zern MA, Hagbjork A-L, Ingelman-Sundberg M, French SW. Fish oil, alcohol and liver pathology. Role of cytochrome P450 2E1. Proc Soc Exp Biol Med 1994:207;197-205.

44. French SW, Takahashi H, Wong K, Mendenhall C. Ito cell activation induced by chronic ethanol feeding in the presence of different dietary fats. Alcohol Alcohol 1991;26(Suppl):357-61.

45. Rockey DC, Maher JJ, Jarnagen WR, Gabbiani G, Friedman SL. Inhibition of rat hepatic lipocyte activation in culture by interferon- $\gamma$. Hepatology 1992;16:776-84.

46. Hogemann B, Domschke W. Hepatic fibrosis-current concepts of pathogenesis and therapy. Gastroenterol Jpn 1993;28:570-9.

47. Herbst H, Wege T, Milani S, et al. Tissue inhibition of metalloproteinase- 1 and 2 RNA expression in rat and human liver fibrosis. Am J Pathol 1997;150:1647-59.

48. Nanji AA, Tahan SR, Khwaja S, Yacoub LK, Sadrzadeh SMH. Elevated plasma levels of hyaluronic acid indicate endothelial dysfunction in the initial stages of alcoholic liver disease in the rat. J Hepatol 1996;24:368-74.

49. Bissell DM, Wang FS, Timmons C. Expression of the hyaluronate receptor CD44 by liver stellate cells: Splice isoforms in wound repair and role in cell migration. Mol Biol Cell 1997;8:396. (Abst)

50. Bauer M, Paquette NC, Zhang JX, et al. Chronic ethanol consumption increases hepatic sinusoidal contractile response to endothelin-1 in the rat. Hepatology 1995;22:1565-76.

51. French SW, Benson NC, Sun PS. Centrilobular liver necrosis 
induced by hypoxia in chronic ethanol-fed rats. Hepatology 1984:4:912-7.

52. Ray MB, Mendenhall CL, French SW, Gartside PS. The nature of bile duct changes in alcoholic liver disease. Liver 1993;13:36-45.

53. Cocjin J, Rosenthal P, Bulson V, et al. Bile ductule formation in fetal neonatal and infant livers compared with extrahepatic biliary atresia. Hepatology 1996;24:568-74.

54. Thorgiersson SS. Hepatic stem cells in liver regeneration. FASEB J 1996;10:1249-56.

55. Fuji K, Evarts RP, Hu Z, Marsden ER, Thorgeirsson SC. Expression of stem cell factor and its receptor c-kit during liver regeneration from putative stem cells in adult rat. Lab Invest 1994;70:511-6.

56. Rockey DC, Fovassier L, Chung JJ, et al. Cellular localization of endothelin-1 and increased production in liver injury in the rat: Potential for autocrine and paracrine effects on stellate cells. Hepatology 1998;27:472-80.

57. Omori M, Evarts RP, Omori N, Hu Z, Marsden ER, Thorgierson SS. Expression of $\alpha$-fetoprotein and stem cell factor/c-kit system in bile duct ligated young rats. Hepatology 1997;25:1115-22.

58. Matsumoto K, Fuji H, Michalopoulus G, Fung JJ, Demetris AJ. Human biliary epithelial cells secretic and respond to cytokines, and hepatocytic growth factors in vitro: Interleukin-6, hepatocyte growth factor and epidermal growth factor promote DNA synthesis in vitro. Hepatology 1994;20:376-82.

59. Zhang-Gouillon ZQ, Yuan QX, Hu B, et al. Mallory body formation by ethanol feeding in drug-primed mice. Hepatology $1998 ; 27: 116-22$.
60. Yuan QX, Nagao Y, Gaal K, Hu B, French SW. Mechanisms of Mallory body formation induced by okadaic acid in drug primed mice. Exp Mol Pathol 1998;65:87-103.

61. Kachi K, Wong PTT, French SW. Molecular structural changes in Mallory body protein in human and mouse livers. An infrared spectroscopy study. Exp Mol Pathol 1993;59:187-210.

62. Ohta M, Marceau N, Perry C, et al. Ubiquitin is present on the cytokeratin intermediate filaments and Mallory bodies of hepatocytes. Lab Invest 1988;59:848-56.

63. Kawahara H, Cadrin M, French SW. Ethanol-induced phosphorylation of cytokeratin in cultured hepatocytes. Life Sci 1990;47:859-63.

64. French SW. Cytoskeleton: Intermediate filaments. In: Arias IM, Boyer JL, Fausto N, Jakoby WB, Schachter DA, Shafritz DA, eds. the Liver: Biology and Pathobiology, 3rd edn. New York: Raven Press, 1994:33-44.

65. Sun SC, Magqirwar SR, Harhad E. Activation of NF kappa b by phosphatase inhibitors involves the phosphorylation of I kappa B alpha at phosphatase 2A-sensitive sites. J Biol Chem 1995;270:18347-51.

66. Stumptner C, Omary MB, Denk H, Zatloukal K. Changes in the phosphorylation of the hepatic keratins $8 / 18$ in human alcoholic hepatitis and in experimentally intoxicated mouse liver. Hepatology 1998;28:512. (Abst)

67. Guertl B, Stumptner C, Zatloukal K, Denk H. Role of protein kinases and phosphatases in the pathogenesis of liver disease and related animal models. Hepatology 1998;28:638. (Abst) 


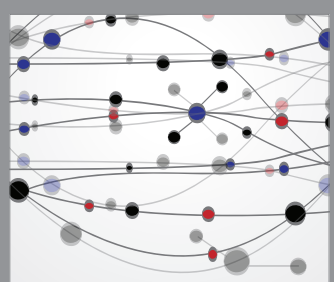

The Scientific World Journal
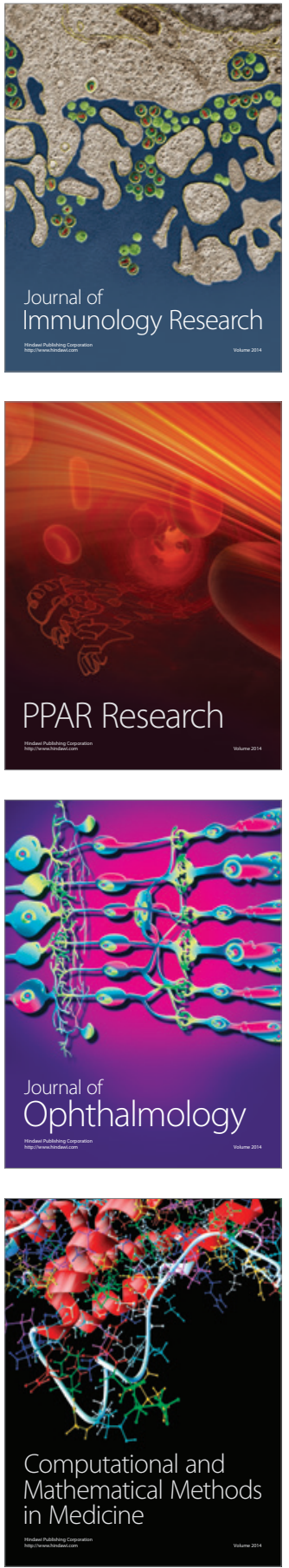

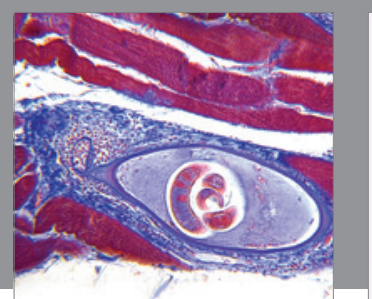

Gastroenterology Research and Practice

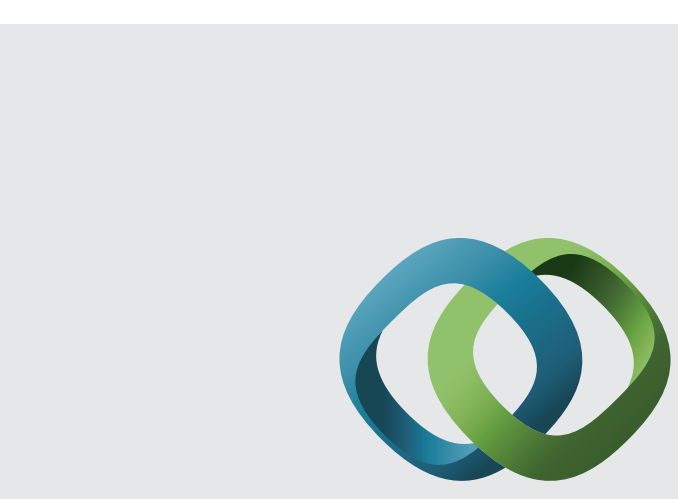

\section{Hindawi}

Submit your manuscripts at

http://www.hindawi.com
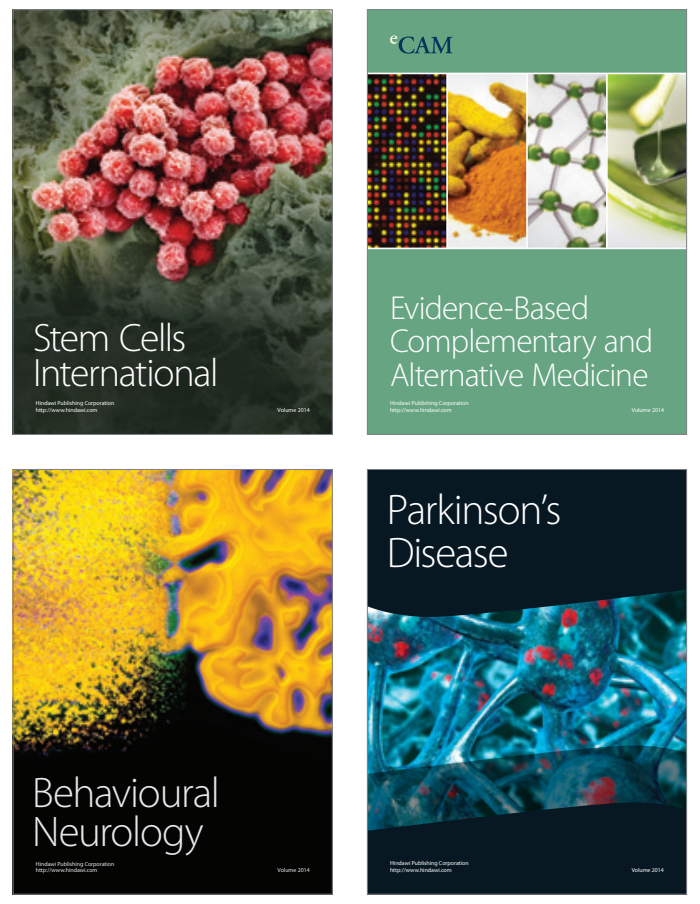
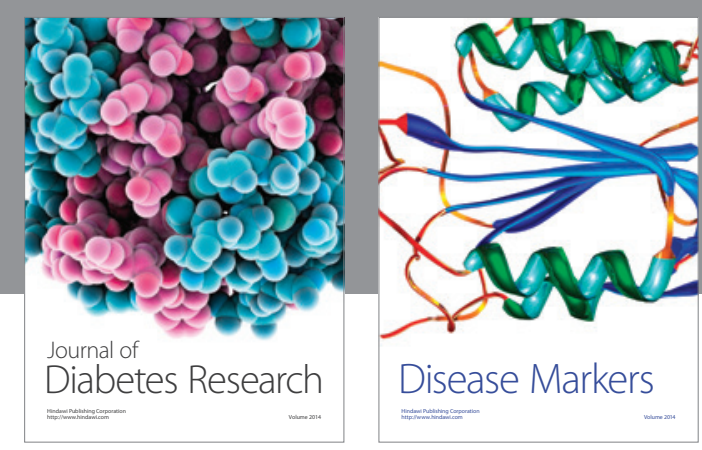

Disease Markers
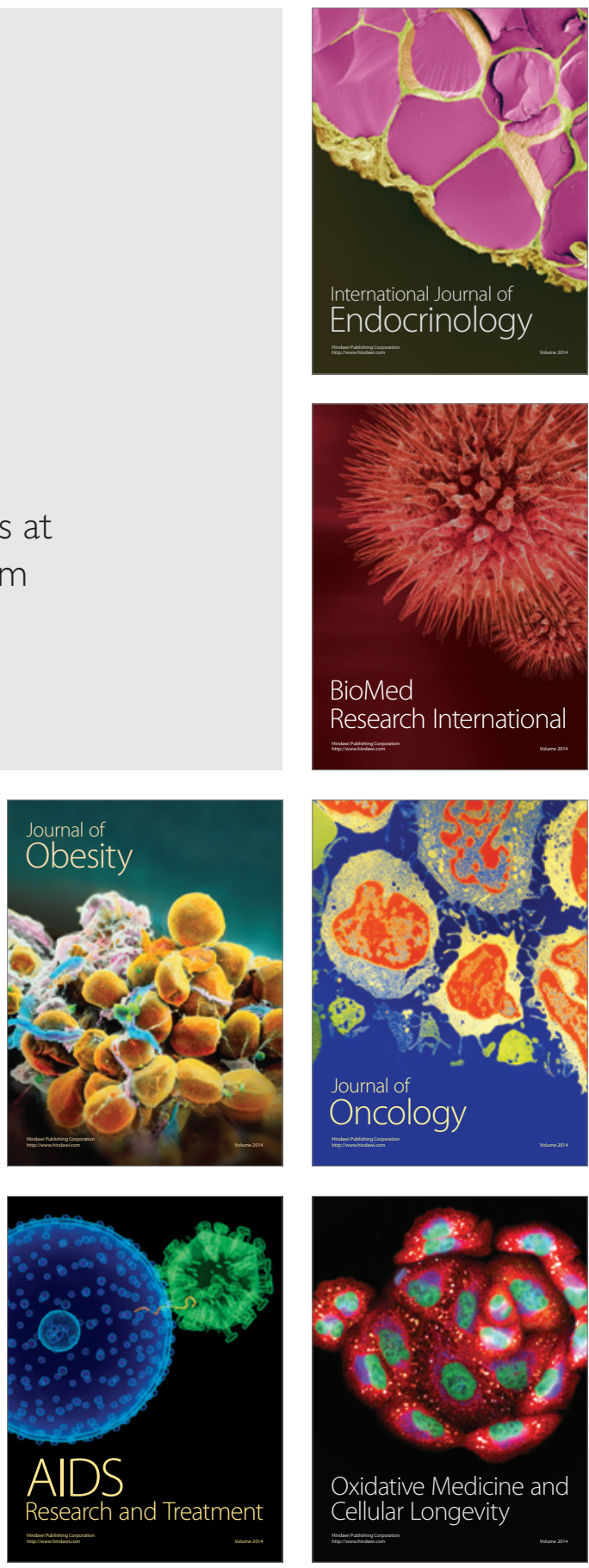